\title{
ANALISIS TINGKAT KEPUASAN MASYARAKAT TERHADAP PELAYANAN PUBLIK PADA KANTOR KECAMATAN GADING CEMPAKA KOTA BENGKULU
}

\section{Oleh:}

Markoni $^{1}$

\begin{abstract}
ABSTRAKSI
Dari penelitian ini diharapkan diperoleh informasi tentang Tingkat Kepuasan Masyarakat terhadap Pelayanan Publik pada Kantor Kecamatan Gading Cempaka Kota Bengkulu. Untuk maksud tersebut diambil sampel sebanyak 50 Orang dengan teknik accidental sampling. Pengumpulan Data dilakukan dengan penyebaran Kuisioner terhadap sampel yang terpilih, serta dilengkapi dengan metode wawancara. Alat analisis yang digunakan untuk mengetahui tingkat kepuasan masyarakat menggunakan metode Customer Satisfaction Index (CSI), dengan memperhitungkan Kepentingan Masyarakat dan Tingkat Kinerja Pegawai. Sedangkan aspek-aspek yang dinilai meliputi Kejelasan Informasi, Kemudahan Persyaratan, Kecepatan Pelayanan, Kesamaan Perlakuan Pelayanan, Keramahan Petugas serta Kenyamanan Lingkungan. Dari hasil analisis diperolah rata-rata Penilaian tertinggi untuk tingkat kepentingan masyarakat adalah aspek Kejelasan Informasi, diikuti aspek aspek Kecepatan Pelayanan, Kenyamanan Lingkungan, Kesamaan Perlakuan Pelayanan, Kemudahan Persyaratan dan yang terendah adalah aspek Keramahan Petugas. Rata-rata Penilaian tertinggi untuk tingkat Kinerja pegawai adalah aspek Kenyamanan Lingkungan, selanjutnya diikuti aspek aspek Kejelasan Informasi, Keramahan Petugas, Kecepatan Pelayanan, Kesamaan Perlakuan Pelayanan dan yang terendah adalah aspek Kemudahan Persyaratan. Nilai Customer Satisfaction Index (CSI) sebesar 59,0804\%, menunjukkan Tingkat Kepuasan Masyarakat terhadap Pelayanan Publik di Kantor Kecamatan Gading Cempaka Kota Bengkulu dapat dikatakan puas.Aspek aspek yang perlu dipertahankan adalah Kejelasan Informasi, Kenyamanan Lingkungan dan Keramahan Petugas.Aspek aspek yang perlu diperbaiki adalah Kecepatan Pelayanan, Kesamaan Perlakuan Pelayanan dan Kemudahan Persyaratan.
\end{abstract}

Kata Kunci : Kepuasan Masyarakat, Pelayanan Publik

\footnotetext{
${ }^{1}$ Dosen Tetap Fakultas Ekonomi Unihaz Bengkulu
} 


\section{A. Pendahuluan}

Untuk mencapai Visi Kecamatan Gading Cempaka Kota Bengkulu, yaitu terwujudnya pelayanan prima yang professional dan kridibel di Kecamatan Gading Cempaka Kota Bengkulu, maka semua sumber daya terutama sumber daya manusia atau pegawai Kecamatan Gading Cempaka Kota Bengkulu haruslah mempunyai skill dan bekerja secara professional sesuai dengan tugas pokok dan fungsi masing masing pegawai.

Setiap masyarakat yang membutuhkan pelayanan dari pegawai Kecamatan Gading Cempaka Kota Bengkulu sangat mengharapkan urusannya di Kecamatan Gading Cempaka Kota Bengkulu dapat selesai dengan cepat dan memuaskan, seperti urusan surat pengantar pembuatan Kartu Keluarga, surat pengantar Kartu Tanda Penduduk, surat pengantar mendapatkan Surat keterangan catatan kejahatan, surat keterangan belum menikah dan sebagainya.

Kepuasan masyarakat di suatu kecamatan menunjukkan tingkat kinerja pegawai kecamatan tersebut sekaligus pula akan menunjukkan kinerja pemerintah kecamatan tersebut. Dalam lingkup yang lebih luas kinerja pemerintahan kecamatan akan mencerminkan kinerja pemerintahan kota, pemerintahan propinsi dan seterusnya.

Mengingat pentingnya kepuasan masyarakat tersebut, maka setiap unit organisasi, baik lembaga pemerintah maupun swasta, baik lembaga bisnis, maupun lembaga pendidikan, akan memberikan perhatian yang optimal terhadap mutu layanan kepada masyarakat, pelanggan atau konsumen bagi lembaga bisnis.

Untuk memberikan pelayanan yang prima tersebut, Dinas instansi atau lembaga menetapkan Standar Mutu, petujuk pelaksanaan mutu, membentuk unit penjaminan mutu (UPM), Gugus Kendali Mutu (GKM), system dan sub system kendali mutu, serta dilengkapi dengan Pedoman Pelaksanaan, Standar Operasional Prosedur (SOP) dan sebagainya. Proses penjaminan mutu itu sendiri selalu di pantau (dimonitor) dan dievaluasi agar pelaksanaan pelayanan sesuai dengan standar mutu yang sudah ditetapkan.

Berdasarkan permasalahan di atas, maka penelitian ini dapat dirumuskan permasalahan yaitu: bagaimana tingkat kepuasan masyarakat terhadap pelayanan publik pada Kantor Kecamatan Gading Cempaka Kota Bengkulu .

Adapun tujuan dari penelitian ini adalah untuk mengetahui tingkat kepuasan masyarakat terhadap Kualitas Pelayanan Pegawai Kantor Kecamatan Gading Cempaka Kota Bengkulu.

\section{B. Metode Penelitian}

Penelitian ini bersifat deskriftif dalam artian tidak bertujuan untuk menguji hipotesis melainkan untuk memberikan gambaran realitas sosial bagaimana tingkat kepuasan masyarakat terhadap pelayanan Publik pada Kantor Kecamatan Gading Cempaka Kota Bengkulu. Data yang digunakan merupakan data Primer dan data Sekunder. Populasi penelitian adalah semua Masyarakat yang berurusan di Kantor Kecamatan Gading Cempaka Kota Bengkulu, dengan jumlah sampel sebanyak 50 orang. Pengambilan sampel dilakukan dengan teknik accidental sampling, dan Pengumpulan data dilakukan dengan teknik Observasi , wawancara dan Kuisioner.

Untuk mengetaui tingkat kepuasan masyarakat terhadap kualitas pelayanan Publik pada Kecamatan Gading Cempaka Kota Bengkulu digunakan alat analisis Customer Satisfaction Index (CSI), dengan memperhitungkan: Kepentingan Masyarakat dan Tingkat kinerja pegawai.

\section{Hasil Penelitian dan Pembahasan}

1. Analisis Kepuasan Masyarakat terhadap pelayanan Publik

a. Nilai tingkat kepentingan dan tingkat kinerja dilihat dari Kejelasan Informasi

Berdasarkan analisis tingkat kepentingan dan tingkat kinerja dilihat dari kejelasan informasi bahwa penilaian tertinggi (60\%) responden menganggap Kejelasan Informasi Sangat Penting dan penilaian terendah dengan klasifikasi Cukup Penting $(6 \%)$, sedangkan tingkat penilaian tertinggi untuk kinerja pegawai dari aspek kejelasan informasi (36\% )menganggap baik dan penilaian terendah untuk kinerja Pegawai yaitu Sangat Tidak Baik $(6 \%)$. Sedangkan rata-rata tingkat penilaian terhadap tingkat kepentingan $=4,54$ dan rata-rata tingkat penilaian terhadap tingkat kinerja pegawai $=3,68$ 


\section{b. Nilai kepentingan dan kinerja dilihat dari Kemudahan Persyaratan}

Hasil kuisoner yaitu (50\%) responden menganggap aspek Kemudahan Persyaratan Penting dan penilaian terendah dengan klasifikasi Cukup Penting (14\%), sedangkan tingkat penilaian tertinggi untuk kinerja pegawai dari aspek Kemudahan Persyaratan (42\%) menganggap Baik, dan penilaian terendah untuk kinerja Pegawai yaitu Sangat Tidak Baik ( 8\%). Sedangkan rata-rata tingkat penilaian terhadap tingkat kepentingan $=4,22$ dan rata-rata tingkat penilaian terhadap tingkat kinerja pegawai $=$ 3,30 .

\section{c. Nilai kepentingan dan kinerja dilihat dari Kecepatan Pelayanan}

Hasil kuisoner menyatakan bahwa $(50 \%)$ responden menganggap aspek Kecepatan Pelayanan sangat penting dan penilaian terendah dengan klasifikasi Cukup Penting (10\%), sedangkan tingkat penilaian tertinggi untuk kinerja pegawai dari aspek Kecepatan Pelayanan (32\%) menganggap sangat baik dan penilaian terendah untuk kinerja Pegawai yaitu Sangat Tidak Baik ( $12 \%$ ). Sedangkan rata-rata tingkat penilaian terhadap tingkat kepentingan $=4,4$ dan ratarata tingkat penilaian terhadap tingkat kinerja pegawai $=3,48$.

d. Nilai kepentingan dan kinerja dilihat dari Kesamaan Perlakuan Pelayanan

Hasil menyatakan (44\%) responden menganggap aspek Kesamaan Perlakuan Pelayanan sangat penting, dan penilaian terendah dengan klasifikasi Cukup Penting (16\%), sedangkan tingkat penilaian tertinggi untuk kinerja pegawai dari aspek Kesamaan Perlakuan Pelayanan (30\%) menganggap cukup baik dan penilaian terendah untuk kinerja Pegawai yaitu Sangat Tidak Baik (10\%). Sedangkan rata-rata tingkat penilaian terhadap tingkat kepentingan $=4,28$ dan rata-rata tingkat penilaian terhadap tingkat kinerja pegawai $=$ 3,32

\section{e. Nilai kepentingan dan kinerja dilihat dari Keramahan Petugas}

Hasil menyatakan (48\%) responden menganggap aspek Keramahan Petugas Sangat Penting dan penilaian terendah dengan klasifikasi Tidak Penting (6\%), sedangkan tingkat penilaian tertinggi untuk kinerja pegawai dari aspek Keramahan Petugas (30\%) menganggap Sangat Baik dan
(30\%) menganggap baik, dan penilaian terendah untuk kinerja Pegawai yaitu Tidak Baik (8\%) serta Sangat Tidak Baik (8\%). Sedangkan rata-rata tingkat penilaian terhadap tingkat kepentingan $=4,20$ dan rata-rata tingkat penilaian terhadap tingkat kinerja pegawai $=3,66$

\section{f. Nilai kepentingan dan kinerja dilihat dari Kenyamanan Lingkungan}

Hasil kuisoner menyatakan (50\%) responden menganggap aspek Kenyamanan Lingkungan sangat penting dan penilaian terendah dengan klasifikasi Cukup Penting (20\%), sedangkan tingkat penilaian tertinggi untuk kinerja pegawai dari aspek Kenyamanan Lingkungan (40\%) menganggap sangat baik dan penilaian terendah untuk kinerja Pegawai yaitu Sangat Tidak Baik (8\%). Sedangkan rata-rata tingkat penilaian terhadap tingkat kepentingan $=4,30$ dan rata-rata tingkat penilaian terhadap tingkat kinerja pegawai $=$ 3,82 .

g. Kepuasan Masyarakat terhadap pelayanan Publik di Kantor Kecamatan Gading Cempaka

Berdasarkan hasil hitung Rata-rata tingkat kepentingan sebesar 4,35, dengan tingkat kepentingan yang tertinggi dilihat dari aspek Kejelasan Informasi yaitu 4,54, dan tingkat kepentingan yang terendah dari aspek Keramahan Petugas 4,2. Sedangkan Rata-rata tingkat kinerja pegawai sebesar 3,54 , dengan tingkat kinerja pegawai yang tertinggi dilihat dari aspek kenyamanan Lingkungan yaitu 3,82, Sedang kantingkat kinerja pegawai yang terendah dari aspek kemudahan persyaratan yaitu 3,30 .

Selanjutnya atas dasar Rata-Rata Penilaian Tingkat Kepentingan dan kinerja seperti tersebut pada Tabel dibawah ini, dilakukan perhitungan Indeks kepuasan Masyarakat sebagai berikut: 
MIMBAR

JURNAL PENELITIAN SOSIAL DAN POLITIK

September - Desember $2017 \quad$ ISSN : 2252-5270

Tabel : Tingkat Kepuasan Masyarakat

\begin{tabular}{|c|c|c|c|c|}
\hline $\begin{array}{c}\text { Customer } \\
\text { Satisfaction Index } \\
\text { (CSI) Tingkat } \\
\text { Kepuasan } \\
\text { MasyarakatAspek } \\
\text { produk } \\
\end{array}$ & $\begin{array}{c}\text { Rata-rata } \\
\text { tingkat } \\
\text { kepentingan }\end{array}$ & $\begin{array}{l}\text { Importance } \\
\text { weighting } \\
\text { factor }(\%)\end{array}$ & $\begin{array}{c}\text { Rata-rata } \\
\text { tingkat } \\
\text { kinerja }\end{array}$ & $\begin{array}{c}\text { Weighted } \\
\text { score } \\
(\%)\end{array}$ \\
\hline Kejelasan Informasi & 4.54 & 17.5 & 3.68 & 0.644070933 \\
\hline $\begin{array}{l}\text { Kemudahan } \\
\text { Persyaratan }\end{array}$ & 4.22 & 16.27 & 3.30 & 0.536854279 \\
\hline Kecepatan Pelayanan & 4.4 & 16.96 & 3.48 & 0.590285274 \\
\hline $\begin{array}{l}\text { Kesamaan Perlakuan } \\
\text { Pelayanan }\end{array}$ & 4.28 & 16.5 & 3.32 & 0.547787201 \\
\hline Keramahan Petugas & 4.2 & 16.19 & 3.66 & 0.592598304 \\
\hline $\begin{array}{l}\text { Kenvamanan } \\
\text { Lingkungan }\end{array}$ & 4.3 & 16.58 & 3,82 & 0.633230532 \\
\hline Total & 25,94 & 100 & 21.26 & \\
\hline Weighted total & & & & 3,5448 \\
\hline $\begin{array}{c}\text { Satisfaction index } \\
(\%) \\
(\mathrm{CSI}=(\mathrm{WT}: 6) \mathrm{X} \\
100 \%)\end{array}$ & \multicolumn{3}{|c|}{$(3,5448: 6) \times 100 \%$} & 59,0804 \\
\hline
\end{tabular}

Berdasarkan hasil perhitungan Indeks Kepuasan Masyarakat (CSI) tersebut pada Tabel X di atas, diketahui bahwa nilai Customer Satisfaction Index (CSI) sebesar 59,0804 \%, maka tingkat kepuasan Masyarakat terhadap Pelayanan Publik di Kantor Kecamatan Gading Cempaka Kota Bengkulu dapat dikatakan puas.

Berdasarkan Persentase Weighted score, aspek aspek yang harus dipertahankan adalah aspek Kejelasan Informasi, Kenyamanan Lingkungan serta Keramahan Petugas. Sedangkan aspek aspek yang masih harus diperbaiki dan ditingkatkan yaitu meliputi aspek-aspek Kemudahan Persyaratan, Kecepatan Pelayanan, dan Kesamaan Perlakuan Pelayanan.

\section{Kesimpulan dan Saran}

\section{Kesimpulan}

Berdasarkan uraian di atas maka dapat disimpulkan:

1. Penilaian tertinggi untuk tingkat kepentingan bagi masyarakat adalah aspek Kejelasan Informasi, diikuti aspek aspek Kecepatan Pelayanan, Kenyamanan Lingkungan, Kesamaan Perlakuan Pelayanan, Kemudahan Persyaratan dan yang terendah adalah aspek Keramahan Petugas.

2. Penilaian tertinggi untuk tingkat Kinerja pegawai adalah aspek Kenyamanan Lingkungan, selanjutnya diikuti aspek aspek Kejelasan Informasi, Keramahan Petugas, Kecepatan Pelayanan, Kesamaan Perlakuan Pelayanan dan yang terendah adalah aspek Kemudahan Persyaratan.

3. Nilai Customer Satisfaction Index (CSI) sebesar 59,0804 \%, menunjukkan Tingkat Kepuasan Masyarakat terhadap Pelayanan Publik di Kantor Kecamatan Gading Cempaka Kota Bengkulu dapat dikatakan puas.

2. Saran

Saran yang dapat diberikan sebagai berikut :

1. Aspek aspek yang perlu dipertahankan adalah Kejelasan Informasi, Kenyamanan Lingkungan dan Keramahan Petugas.

2. Aspek aspek yang perlu diperbaiki adalah Kecepatan Pelayanan, Kesamaan Perlakuan Pelayanan dan Kemudahan Persyaratan.

\section{DAFTAR PUSTAKA}

Sumber dari Buku :

Atep, Adtya, Barata, 2004, Dasar-dasar Pelayanan Prima, Jakarta : PT. Elex Media Komputindo.

Dwiyanto, Agus, 2008. Mewujudkan Good Governance Melalui Pelayanan Publik, Yogyakarta: Gadjah Mada University Press.

Dwiyanto, Agustus.,dkk, 2006. Reformasi Birokrasi Publik di Indonesia, Yogyakarta: Gadjah Mada University Press.

Dwiyanto, Agus, 2011. Mengembalikan Kepercayaan Publik Melalui Reformasi Birokrasi, Jakarta : PT Gramedia Pustaka Utama.

Hardiyansyah, 2011, Kualitas Pelayanan Publik, Yogyakarta: Gava Media.

Hasibuan Sinungan, 2003. Manajemen Sumber daya Manusia. Bandung CV.Pustaka Setia;

Siagian, Sondang P, 2002, Manajemen Surnber Daya Manusia. Bumi Aksara, Jakarta Cetakan Kelima;

Tjiptono, Fandy dan Anastasia Diana. 2003. Total Quality Manajemen. Edisi Revisi. Andy: Yogyakarta;

\section{Sumber Non Buku :}

Supranto,j. 2001.pengukuran tingkat kepusaan pelanggan untuk meningkatkan pangsan pasar PT.RenitaCipta Jakarta (http://pse.litbang.deptan.go.id/ind/pdffi les/JAE\%2024-1c.pdf);

http://etalasepustaka.blogspot.co.id/2016/08/ pengertian-indikator-kepuasanpelanggan-menurut-para-ahli.html;

https://raninuraeni379.wordpress.com/kuliah /administrasi-publik/indeks-kepuasan- 
MIMBAR

JURNAL PENELITIAN SOSIAL DAN POLITIK

September-Desember 2017

masyarakat-ikm/;

http://www.materibelajar.id/2016/03/pengert

ian-pelayanan-publik-dan-

standar.html) 